\title{
STRUCTURAL CHANGES AND PROSPECTS OF THE DEVELOPMENT OF VEGETABLE PRODUCTION IN BULGARIA
}

\author{
Venelin Terziev ${ }^{1}$ and Teodora Stoeva ${ }^{2}$ \\ ${ }^{1}$ Full Member of the Russian Academy of Natural History, Professor, Eng., D.Sc. (National \\ Security), D.Sc. (Economics), D.Sc. (Social Activities), Ph.D., Russian Academy of Natural History, \\ Moscow, Russia, Vasil Levski National Military University, Veliko Tarnovo, Bulgaria University of \\ Rousse, Rousse, Bulgaria, terziev@skmat.com \\ ${ }^{2}$ Associate Professor, Ph.D., Agricultural University - Plovdiv, Bulgaria, teodorastoeva@gmail.com
}

\begin{abstract}
The agricultural sector has always been a strategic branch of Bulgarian economy. Bulgaria has many years of experience, well-established traditions and opportunities in the sphere of agriculture and particularly in vegetable production. The evaluation and analysis of the contemporary situation for the development of vegetable production are issues of current importance for Bulgarian agriculture in the context of the Common agricultural policy. The aim of this article is to present the problems and the trends of changes in the Bulgarian vegetable production related to the sustainable economic development of Bulgaria.
\end{abstract}

Keywords: vegetable production, development, agricultural sector.

\section{INTRODUCTION}

By tradition, the agriculture has been a major sector of Bulgarian economy because of its crucial social and economic significance. After the accession of Bulgaria to the EU the agricultural sector has been facing a lot of opportunities as well as issues related to the application of the rules of the Common agricultural policy and the strong competition from other European countries.

The presence of favourable natural and climatic conditions, longstanding traditions, wealth of experience, development of new technological solutions, use of modern varieties with high biological potential, outline the tendencies for market survival and development of the vegetable farms. The good prerequisites for the development of vegetable production in Bulgaria determine the diversity of vegetables grown.

Bulgarian vegetable production, which is a traditional sub-sector of plant production, has been experiencing considerable difficulties in adapting to the new market situation ever since 2007 and it finds it difficult to develop its economic and industrial potential. The presence of favourable natural and climatic conditions, the longstanding traditions, wealth of experience, the development of new technological solutions, the use of modern varieties with high biological potential outline the prerequisites and conditions for the development of Bulgarian vegetable farms.

Having in mind the current development of the industry, the notable importance of vegetable production has not been realized. Recently, there is a lasting tendency of decrease in harvested areas and the realization of average yields which is far from the biologic potential of the cultivated crops. Often, the production harvested 
is of weak competitiveness in terms of the increasing quality demands of the national, regional and common European market. The availability of suitable soil and climatic conditions, the long-lasting traditions, rich practical experience, the existence and development of new technological solutions and market-oriented innovations, the utilization of contemporary varieties of high biological potential outline favorable trends for the development of vegetable production in the country. They reveal opportunities for broader integration of the sector in rural areas for the achievement of highly efficient and competitive production (Yovchevska, et al. 2019).

\section{THEORETICAL STUDY}

To achieve the objective pursued, the statistical yearbooks and reference books of the National Statistical Institute (NSI) have been used as well as the agricultural reports of the Ministry of agriculture and food, newsletters of the Agrostatistics Directorate to the Ministry of agriculture and food, and own researches. For the purposes of the research different information sources have been used - scientific journals, publications by Bulgarian and foreign authors, on-line (electronic) periodicals, as well as the author's own research.

\section{INVESTIGATION RESULTS}

Agricultural production in the country is still characterized by relatively low competitiveness and insufficient market orientation, which to a large extent is caused by the problems accumulated in the sector during the years of transition. Vegetable production is heavily dependent on the natural and climatic conditions in our country and in some cases the varieties used are not resistant to the changes of the natural conditions (drought, high humidity). Undoubtedly, the variety of climatic and soil conditions are good prerequisites for the development of vegetable production, having in mind that most crops are grown in the plains and lowlands of Bulgaria.

The application of the Common agricultural policy puts the competitiveness of Bulgarian agricultural production to a serious test - now it has to compete with the European production, which is relatively cheaper and more attractive in appearance. The import of fruits and vegetables affects the structure and volume of Bulgarian agricultural production.

The return of the land in the situation of "generational vacuum" and destroyed production structures has led mainly to cultivation of cereal crops (Yovchevska, 2016). Intensive industries, including the vegetable sector, are placed in an unfavourable business environment. The choice of income support for farmers after 2007 has deepened the serious crisis in the vegetable production. According to studies by a number of authors, ever since 2007 the competitiveness of Bulgarian vegetable production has faced a number of challenges (Stoeva, 2014). The process has a sustainable nature. The relative share of the total vegetable production in Bulgaria is reduced compared to the production in the agricultural sector, from $19.03 \%$ in 2006 to $3.29 \%$ in 2012 (Yovchevska, 2015).

According to Nikolov, Yovchevska et al. "the technological requirements of this production, which is intensive in nature, as well as the lack of preparation of the sector for strong competition from other EU Member States, the entry of supermarkets in the retail trade, the presence of very small farms in the sector, unfair competition from neighbouring countries, the lack of vegetable producers associations, are part of the factors that have contributed to the current situation of vegetable production and is a sign of extremely unfavourable tendency" (Nikolov et al. 2015).

The analysis of the data shows that in general the harvested areas are small for the country. The reasons for this are the unattractive work, lack of mechanization in the sector, lack of workforce, as well as the low qualification of workers, low pay in the sector which discourages people, as well as non-compliance with the application of technologies for cultivation of vegetable crops.

It must be stated that our country does not effectively exploit its potential for development of vegetable production despite the good conditions it has - favorable soil and climatic conditions, land resources, long traditions and experience in cultivation of vegetables (Popov et al. 2012).

According to the data provided by Agrostatistics Department at the Ministry of Agriculture, Food and Forestry (MAFF), in 2016 there was a continuation of the trend, that had started the previous year, of a substantial increase in the areas of vegetable crops, which was greatly contributed by the coupled support schemes applied to the sector. According to the data provided by Agrostatistics Department at the Ministry of Agriculture, Food and Forestry (MAFF), in 2016 the areas with fruit plantations and berry crops in agricultural holdings took up 58.5 thousand hectares and those used for vegetable production - over 60 thousand hectares, which was respectively $6 \%$ and $30 \%$ more than in 2015 (Table 1) (2018a). 
IJASOS- International E-Journal of Advances in Social Sciences, Vol. V, Issue 15, December 2019

Table 1. Harvested areas of main vegetable crops for Bulgaria, in total and in crops (in Ha).

\begin{tabular}{|c|c|c|c|c|c|c|c|}
\hline Years & $\begin{array}{c}\text { Total } \\
\text { vegetables }\end{array}$ & Tomatoes & Pepper & Cucumbers & Potatoes & Onions & Cabbage \\
\hline 2013 & 14440 & 3242 & 4035 & 592 & 12765 & 1225 & 1903 \\
\hline 2014 & 11857 & 3024 & 2876 & 345 & 10200 & 1118 & 1943 \\
\hline 2015 & 18067 & 2686 & 3681 & 309 & 11017 & 1074 & 1871 \\
\hline 2016 & 28543 & 3613 & 3577 & 247 & 8376 & 1365 & 2875 \\
\hline 2017 & 19232 & 4376 & 3257 & 282 & 12806 & 2080 & 1692 \\
\hline 2018 & 17821 & 3907 & 2854 & 470 & 14096 & 3675 & 1961 \\
\hline
\end{tabular}

Source: Ministry of agriculture and food, Agrostatistics Directorate 2013-2018.

The year was characterized by varying climatic conditions, which had a mixed impact over the fruit and vegetable production. Thus, the total production of vegetables in the country for 2016 marked a significant increase on an annual basis, while the total fruit production had a slight decrease (2018a).

The analysis of the data showed that low yields were due to the use of predominantly foreign varieties and it should be pointed out that, among other reasons such as lack of regionalization in the sector, the requirements for their application did not meet the geographical and climatic conditions of the country for cultivation of vegetable crops. The level of average yields was significantly below the average yields in the EU and the importing countries. Low average yields were mainly due to the use of extensive technologies in the sector and the destroyed hydromeliorative facilities, which made the production of vegetables dependent on weather conditions over the years (Table 2) (Nikolov, Kaneva, Yovchevska, 2018).

Table 2. Average yields of main vegetable crops for Bulgaria (in $\mathrm{kg} / \mathrm{Ha}$ ).

\begin{tabular}{|c|c|c|c|c|c|c|c|}
\hline Years & & Tomatoes & Pepper & Cucumbers & Potatoes & Onions & Cabbage \\
\hline 2013 & 23871 & 14734 & 13914 & 14610 & 10407 & 23694 \\
\hline 2014 & 26603 & 16340 & 19661 & 12999 & 11920 & 21779 \\
\hline 2015 & 26635 & 16936 & 13689 & 14965 & 8311 & 22668 \\
\hline 2016 & 25555 & 19050 & 10668 & 15150 & 10931 & 26265 \\
\hline 2017 & 23434 & 16058 & 16220 & 17782 & 11298 & 24715 \\
\hline 2018 & 21815 & 17083 & 15353 & 18558 & 11374 & 24090 \\
\hline & & & & & & \\
\hline
\end{tabular}

Source: Ministry of agriculture and food, Agrostatistics Directorate 2013-2018.

Despite the positive trends, the production of vegetable crops as a function of areas and yields remains low. Just for comparison, in 1998, the areas planted with field tomatoes reached $276000 \mathrm{dca}$; in 2013 they were 8 times less. In our opinion the reasons for this decline are due to small-scale and fragmented farms, low productivity, depreciated agricultural equipment, limited access to credit, increased production costs and, above all, the fierce competition with the subsidized foreign production that enters our market (Table 3 ). 
IJASOS- International E-Journal of Advances in Social Sciences, Vol. V, Issue 15, December 2019

Table 3. Production of main vegetable crops for Bulgaria, in total and in crops (in tons).

\begin{tabular}{|c|c|c|c|c|c|c|c|}
\hline Years & $\begin{array}{c}\text { Total } \\
\text { vegetables }\end{array}$ & Tomatoes & Pepper & Cucumbers & Potatoes & Onions & Cabbage \\
\hline 2013 & 1567.4 & 272.6 & 141.3 & 62.5 & 600.4 & 36.0 & 138.5 \\
\hline 2014 & 1583.5 & 221.4 & 164.6 & 73.5 & 627.3 & 38.0 & 109.4 \\
\hline 2015 & 1834.5 & 398.0 & 208.6 & 56.1 & 450.1 & 42.2 & 138.0 \\
\hline 2016 & 1590.0 & 238.0 & 125.9 & 87.0 & 573.0 & 45.0 & 117.0 \\
\hline 2017 & 872.6 & 126.4 & 72.1 & 44.7 & 375.5 & 14.3 & 69.3 \\
\hline 2018 & 312905 & 85232 & 48755 & 7216 & 386.0 & 20.2 & 47240 \\
\hline & & & & & & & \\
\hline
\end{tabular}

Source: Ministry of agriculture and food, Agrostatistics Directorate, 2013-2018.

The drastic reduction in production is due to a number of factors. The drop in production volumes can be explained not only with the reduced planted areas, but also with the strong competition in the sector (Nikolov et al. 2015).

Vegetable production also faces a number of issues such as lack of good production organization which is presently characterized by low technological level, large production costs, including high prices of seeds, fertilizers, plant protection products, irrigation water, lack of mechanization and use of human labor in harvesting. The low degree of organization among producers, lack of commercial arrangements between producers and traders regarding the realization of production, low purchase prices of the finished products, lack of manpower in production and use of low-skilled workers - all these are among the pressing issues of the sub-sector awaiting to be solved for years (2013).

Although the natural and climatic conditions are favorable and suitable for the cultivation of a large variety of vegetable crops, the sector is lagging behind dramatically due to technological reasons. Another big problem remains the depreciated irrigation infrastructure, the destroyed hydromeliorative facilities, as well as the increase in the price of irrigation water. The modernization of a large proportion of vegetable farms is at an unsatisfactory level. This leads to a high cost of vegetable production, which results in a loss of market share in favour of the heavily subsidized import production that competes with our vegetables. Production of vegetable crops for the fresh market as well as for processing is a specific sub-sector of plant production. It is distinguished with high labour intensity since it requires different crops and spheres of production to be combined in a way that would provide optimal use of labour force and equipment. Vegetable producers aim at producing such output which realization would provide the greatest possible return in respect of the resources invested for its production - land, labour, capital (Figure.1) (Yovchevska, et al. 2019a).

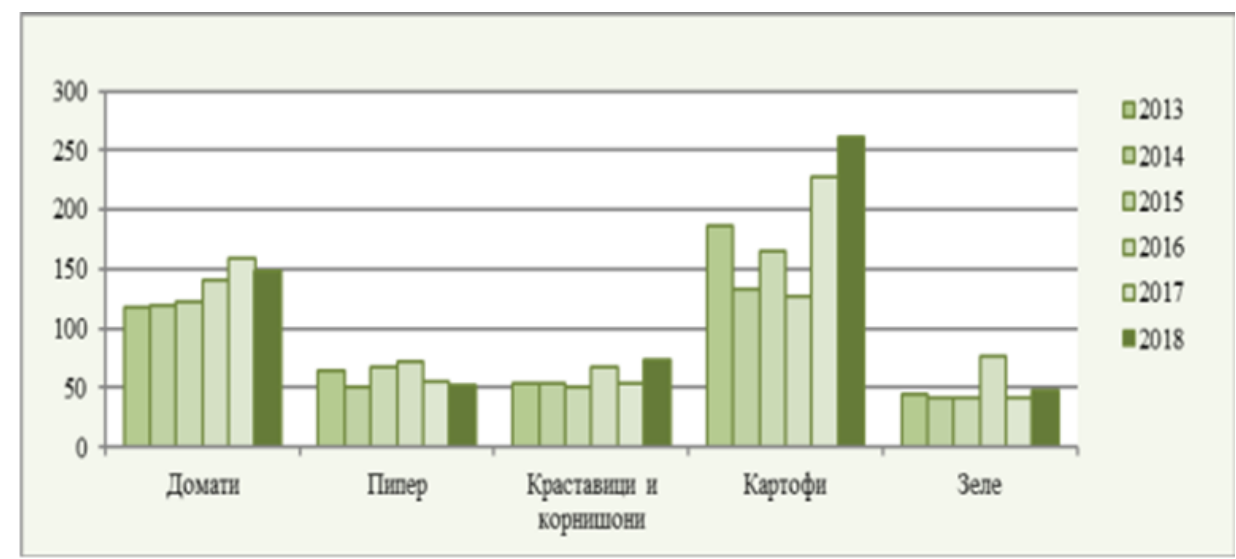

Figure 1. Comparison of production of main vegetables in years (thsnd tons). Source: MAFF, Agrostatistics Department 
In order to take the utmost advantage of the natural resources - soils, rainfall, as well as to increase the efficiency of land use, the following is necessary:

- Preservation of soil fertility by means of introducing an adequate structure and crop rotation, correct content of irrigation regulations in accordance with the biological peculiarities of the crops;

- Preservation of the areas planted with vegetables from erosion by the use of appropriate irrigation methods and irrigation equipment, size of irrigated norms and agronomic techniques that comply with the soil conditions and the peculiarities of the crops;

- The areas planted with vegetables should be designed so that they are in accordance with the irrigation method, irrigation equipment and other agricultural machinery in order to ensure high labour productivity.

Summing up the opinions of different authors, the main trends in the selection of vegetable crops that, to a great extent, will contribute to increasing the competitiveness of vegetable production, can be summarized as follows:

- Breeding of varieties which have high overall resistance to diseases and pests, with opportunities for application of mechanized cultivation and harvesting of production, with excellent technology and taste;

- Creating varieties with a high biological value and valuable technological qualities.

A distinctive feature of vegetable production is the high degree of risk due to the extremely short shelf-life of the products combined with increased sensitivity to temperature changes, diseases and pests, transport and others, which makes vegetable crops perishable products, difficult for market realization. The drastic reduction in production is due to a number of factors. There has been a reduction of farms specializing in vegetable production. The drop in production volumes can be explained not only with the reduced planted areas, but also with the strong competition in the sector.

Due to the fragmentation of the arable land the vegetable production is inefficient and fragmented; the majority of farms are small in size and the biggest part of their production satisfies primarily their own needs while the rest of it, which is offered on the market is of poor quality. Consolidation of arable land will lead to a significant increase in the utilization rate of the production factors and will improve the access to irrigation systems and canals. The advantage of establishing associations is bilateral - the market will also benefit from the actions performed by the professional organizations. Bulgarian vegetable production has some specific distinctive features that turn it into a unique production. The favorable natural and climatic conditions, the longstanding traditions and experience of Bulgarian people in cultivating vegetables and the availability of a wide range of local varieties have a positive effect over the taste of vegetable crops grown in Bulgaria and turn them into marketable products preferred both by consumers and exporters. Unfortunately, the vegetable production is not particularly attractive due to the weak financial support compared to other sub-sectors of the agricultural sector.

A serious problem of the agricultural sector in Bulgaria is the low level of specialization of the farms as a whole. The weak specialization results in an unsatisfactory level of implementation of new technologies, and low competitiveness. Vegetable production is a highly labor-intensive sub-sector of the plant production sector. This requires different crops and spheres of production to be combined in a way that would provide optimal use of labour force and agricultural equipment. The farmers who produce vegetables aim at producing such output which realization would provide the greatest possible return in respect of the resources invested for its production - land, labour, capital.

A serious problem of the agricultural sector in Bulgaria is the low level of specialization of farms as a whole. The weak specialization leads to an unsatisfactory level of implementation of new technologies, and low competitiveness. Vegetable production is a highly labor-intensive sub-sector of the plant production sector. This requires different crops and spheres of production to be combined in a way that would provide optimal use of labour force and agricultural equipment. The farmers who produce vegetables aim at producing such output which realization would provide the greatest possible return in respect of the resources invested for its production - land, labour, capital.

To determine the level of specialization of vegetable farms for the period 2007-2013, we have considered the number of the crops cultivated in each of the surveyed farms. Farms that are specialized in cultivating one main and one additional crop are considered to be of a high level of specialization, farms that are specialized in cultivating two main crops and two additional ones are considered to be of a medium level of specialization, while farms that cultivate two major and four additional crops are considered to be of a low level of specialization.

There are eight farms with a low level of specialization, fifteen farms with a medium level of specialization 
and twenty farms with a high level of specialization. The data presented above shows that the greatest amount of income from $1 \mathrm{dca}$ is obtained in vegetable farms with a high level of specialization - BGN 1396, followed by the farms with a medium level of specialization - BGN 1289, while the income from 1 dca received by the vegetable farms with a low level of specialization is BGN 1025. The other two indicators that show different level of efficiency are in the same sequence: production costs of BGN 100 income in farms with a low level of specialization are the highest - BGN 95,51, in farms with a medium level of specialization they are BGN 86,27 and in farms with a high level of specialization - BGN 72.56. The level of profitability on the basis of production costs is as follows: in farms with a low level of specialization the profitability is $4.49 \%$, in farms with a medium level of specialization the profitability is $21,41 \%$ and in farms with a high level of specialization, the profitability is $27,43 \%$.

From the analysis of the correlation between the level of specialization, income of 1 dca, production cost for BGN 100 income and production profitability of farms producing vegetables in the Plovdiv region for the period 2007-2013, it can be concluded that the best economic results are obtained in specialized farms for production of vegetables with a high level of specialization. The production cost for BGN 100 income in them is the lowest and if compared to the farms with a low level of specialization, the difference amounts to BGN 22,95 . But the profitability of farms with a high level of specialization is greater with $22,94 \%$ (Table 4 ).

\section{Correlation between the level of specialization, income from $1 \mathrm{dca}$, production cost for an income of BGN 100 and profitability of production in farms producing vegetables in the Plovdiv region for the period 2007-2013. Level of specialization.}

\begin{tabular}{|c|c|c|c|}
\hline Indexes & Low & Medium & High \\
\hline Number of crops cultivated & 6 & 4 & 2 \\
\hline Income from 1 dca, BGN & 1025 & 1289 & 1396 \\
\hline $\begin{array}{c}\text { Production costs for an } \\
\text { income of BGN 100 }\end{array}$ & 95.51 & 86.27 & 72.56 \\
\hline Profitability, \% & 4.49 & 21.41 & 27.43 \\
\hline Farms in group & 8 & 15 & 20 \\
\hline
\end{tabular}

Source: author's own research

To improve the organization of the vegetable production it is necessary to consolidate the production which at present is very fragmented and consisting mainly of small family farms. The consolidation and grouping of small-sized agricultural farms will increase the effectiveness and competitiveness of vegetable production. The unification of vegetable production will lead to increase in the level of mechanization of the work processes and mostly the processes associated with the harvesting of crops. It is a well-known fact that vegetable production is one of the most labor-intensive sub-sectors of the agricultural sector, with a high share of manual work - about $80-90 \%$ of the total labor input. Bulgarian vegetable production faces a major challenge and it is the modernization of production, which will increase the production competitiveness so that the vegetable products to meet the current quality requirements and to compete with the imported vegetables (2011; 2011a; Ivanova, Andonov, Enimanev, 2001; Andonov, Koev, Enimanev, Novakova, 2001a; Koev, Enimanev, Andonov, 2001b; Andonov, Koev, Enimanev, Dimov, 2001c; Krasteva, Andonov, Enimanev, Popov, 2004; Novakova, Andonov, Enimanev, 2007; Andonov, Enimanev et al. 2002; Ivanova, Enimanev, Andonov, 2003; Stoyanova, Enimanev, Dudushki, 2010; Novakova, Enimanev, et al. 2007).

\section{CONCLUSION}

The priorities and challenges facing the Bulgarian vegetable production after the accession of our country to the common European market in 2007, are connected with the opportunities for market survival, the overcoming of the low competitiveness of agricultural production as well as with the perspectives for sustainable development of this traditional sub-sector of Bulgarian agriculture. Bulgarian vegetable production has been subjected to a constant pressure by the competitive import of cheap vegetable production from other European countries. 
The stimulation of vegetable producers to aim at competitive and quality vegetable production in conformity with the requirements of the European markets and consumers, as well as the availability of opportunities for sustainable development of specialized vegetable farms, should be a priority of the Bulgarian agricultural policy. Bulgarian agricultural policy should have clear priorities for the development of agriculture and its transformation into a competitive and highly effective branch of Bulgarian economy.

\section{REFERENCE LIST}

Yovchevska, Plamena (2016). Project HTAl-134: Land relations and land market under the conditions of Common agricultural policy (CAP). (2016). Agricultural Academy. Institute of Agricultural Economy. 2016, pp. 5 -7, (Head: Prof. Dr. Plamena Yovchevska).

Stoeva, Teodora. (2014). Challenges associated with the development of vegetable production in Bulgaria after the EU enlargement. // Economics and management of agriculture, pp. 39-42. Year LIX. Issue $4 / 2014$.

Yovchevska, Plamena. (2015). Analysis of the sectors with coupled support. // Institute of agricultural economics - Sofia. Publishing house: Institute of Agricultural Economy-Sofia. 2015, pp.19-20, ISBN 978-619-90180-3-3.

Nikolov, D., Yovchevska, Pl., Chopeva, M., Kaneva, N. et al. (2015a). Analysis of the sectors with coupled support, Institute of agricultural economics - Sofia, 2015, p.34, ISBN 978-619-90180-3-3.

Popov, R., Ivanov, B., Jongeneel, R., Sokolova, E. (2012). How to create a viable and competitive agriculture: assessing the optimal policy measure mix for the case of Bulgaria- Institute of agricultural economics - Sofia, Netherlands Institute of Agricultural Economics at the Wageningen University /LEI/, 2012.

Nikolov, D., Kr. Kaneva, PI. Yovchevska. (2018). Bulgarian agriculture: ten years CAP - results and future challenges after 2020. B: Agriculture and rural areas in Bulgaria and Poland in CAP for the period 2014-2020 and after 2020. Sofia. Publishing house: Institute of Agricultural Economy, 2018, p.9-22, ISBN 978-954-8612-14-2.

Agrostatistics Department, Ministry of agriculture and food. (2018). Farm structure survey in 2016.

National strategy for sustainable development of agriculture in Bulgaria for the period 2014-202 (2013). Ministry of agriculture and food, p.21; p.122; p.125.

Agrostatistics Directorate. (2011). Ministry of agriculture and food, 2011.

Paying agency; State Fund "Agriculture" (2011a). Ministry of agriculture and food, (2011).

Yovchevska, P. et al. (2019). Land relations: theory, practice, perspectives, Institute of Agricultural Economy, Sofia, 2019, p.62.

Yovchevska, PI. et al. (2019a). Land relations: theory, practice, perspectives, Institute of Agricultural Economy, Sofia, 2019, p. 52.

Ivanova, D., Andonov, K., Enimanev, K. (2001). Optimizirane na protsesa v sushilnya za plodove i zelenchutsi. // Selskostopanska tehnika, Sofiya, XXXVIII, 1 (2001), s. 22-25, ISSN 0037-1718 (Иванова, Д., Андонов, К., Ениманев, К. Оптимизиране на процеса в сушилня за плодове и зеленчуци. // Селскостопанска техника, София, XXXVIII, 1 (2001), с. 22-25, ISSN 0037-1718).

Andonov, K., Koev, K., Enimanev, K., Novakova, A. (2001a). Izsledvane na energoikonomichni rezhimi na kamera za sahranyavane na produktsiya. // Selskostopanska tehnika, Sofiya, XXXVIII, 4 (2001), s. 2128, ISSN 0037-1718 (Андонов, К., Коев, К., Ениманев, К., Новакова, А. Изследване на енергоикономични режими на камера за съхраняване на продукция. // Селскостопанска техника, София, XXXVIII, 4 (2001), с. 21-28, ISSN 0037-1718).

Koev, K., Enimanev, K., Andonov, K. (2001b). Izsledvane moshtnostta na ventilatora na kamera za sahranyavane na produktsiya. // Selskostopanska tehnika, Sofiya, XXXVIII, 5 (2001), s. 28-32, ISSN 0037-1718 (Коев, К., Ениманев, К., Андонов, К. Изследване мощността на вентилатора на камера за съхраняване на продукция. // Селскостопанска техника, София, XXXVIII, 5 (2001), с. 28-32, ISSN 0037-1718). 
Andonov, K., Koev, K., Enimanev, K., Dimov, D. (2001c). Tehniko-ikonomicheska otsenka na energiyniya potentsial na atmosferniya vazduh pri sahranenie na produktsiya. // Selskostopanska tehnika, Sofiya, XXXVIII, 2 (2001), s. 17-22, ISSN 0037-1718 (Андонов, К., Коев, К., Ениманев, К., Димов, Д. Технико-икономическа оценка на енергийния потенциал на атмосферния въздух при съхранение на продукция. // Селскостопанска техника, София, XXXVIII, 2 (2001), с. 17-22, ISSN 0037-1718).

Krasteva, A., Andonov, A., Enimanev, K., Popov, G. (2004). Energy efficiency of pump devices at the standard level. // EE\&AE 2004- International Scientific conference 03-05.06.2004, Rousse, Proceedings of the Union of Scientists - Rousse, 3, 2004, pp. 671-675, ISSN 1311-9974.

Novakova, A., Andonov, K., Enimanev, K. (2007). Energy ecological model for reengineering of the production of dried and storage of fresh products. // Ecology and future, Sofia, 6, 2007, 2, pp. 33-41, ISSN 1312-076X.

Andonov, K., Enimanev, K., Martev, K., Daskalov, P., Stojanov, V. (2002). Model of installation with combined energy supply for drying and storage of production. // EE\&AE 2002- International Scientific conference 04-06. 04. 2002, Proceedings of the Union of Scientists - Rousse, Energy efficiency and agricultural engineering, 2, 2002, pp. 182-192, ISSN 1311-9974.

Ivanova, D., Enimanev, K., Andonov, K. (2003). Energy and economic effectiveness of a fruit and vegetable dryer // Energy Conversion and Management, 44, 2003, 5, pp. 763-769, ISSN0196-8904.

Stoyanova, N., Enimanev, K., Dudushki, I. (2010). Izsledvane na model za periodichna profilaktika vazstanovyavashta tehnicheskata izpravnost na zemedelskite mashini. // Industrialen menidzhmant, Sofiya, VII, 13 (2010), s. 31-37, ISSN 1312-3793 (Стоянова, Н., Ениманев, К., Дудушки, И. Изследване на модел за периодична профилактика възстановяваща техническата изправност на земеделските машини. // Индустриален мениджмънт, София, VII, 13 (2010), с. 31-37, ISSN 1312-3793).

Novakova, A., Enimanev, K., Andonov, K., Ermenkov, T. (2007). Izsledvane na netnite ikonomii na vlazhniya vazduh pri sushene. // Ikonomika i upravlenie na selskoto stopanstvo, Sofiya, LII, 6/ 2007, s. 27-33, ISSN 0205-3845 (Новакова, А., Ениманев, К., Андонов, К., Ерменков, Т. Изследване на нетните икономии на влажния въздух при сушене. // Икономика и управление на селското стопанство, София, LII, 6/ 2007, с. 27-33, ISSN 0205-3845).

Nikolov et al. (2015). Analysis of the sectors with coupled support", Institute of Agricultural Economy, Sofia, 2015, p.19.

Enimanev, Krasimir. (2019). Energoefektivno osiguryavane na mikroklimata v zatvoreni agrarni sgradi chrez unifitsirani modulni elementi. Fakultet „Aviatsionen“, Natsionalen Voenen Universitet „Vasil Levski“, Dolna Mitropoliya, 2019, 224 str., ISBN 978-954-713-130-9 (Ениманев, Красимир. Енергоефективно осигуряване на микроклимата в затворени аграрни сгради чрез унифицирани модулни елементи. Факултет „Авиационен“, Национален Военен Университет „Васил Левски“, Долна Митрополия, 2019, 224 стр., ISBN 978-954-713-130-9). 